\title{
An Assessment of Entrepreneurship Programme towards Modern Agri-Technology Usage in Serdang, Selangor, Malaysia
}

\author{
Muhammad Hafidz Abdul Raman ${ }^{1}$, Azizan Asmuni ${ }^{3}$, Khairuddin Idris ${ }^{3}$, Salmizi Saad ${ }^{2}$ \& Vikrul Adzim Azmin ${ }^{1}$ \\ ${ }^{1}$ Department of Agriculture Technology, Faculty of Agriculture, Universiti Putra Malaysia, UPM Serdang, \\ Selangor, Malaysia \\ ${ }^{2}$ Malaysian Agriculture Research and Development Institute, Serdang, Selangor, Malaysia \\ ${ }^{3}$ Faculty of Educational Studies, Universiti Putra Malaysia, UPM Serdang, Selangor, Malaysia \\ Correspondence: Muhammad Hafidz Abdul Raman, Department of Agriculture Technology, Faculty of \\ Agriculture, 43300 UPM Serdang, Universiti Putra Malaysia, Malaysia. Tel: 60-3-8947-4961; 60-12-270-4429. \\ E-mail: muhdhafidz@upm.edu.my; apisraman@gmail.com
}

\author{
Received: April 4, 2014 Accepted: August 26, 2014 Online Published: October 30, 2014 \\ doi:10.5539/ass.v10n22p303 URL: http://dx.doi.org/10.5539/ass.v10n22p303
}

\begin{abstract}
Problem Statement: Malaysia is generally driven by a service oriented industry whereby agriculture was placed at the third ranks of government economic priority. In the agriculture sector, the human capital empowerment has contributed towards agriculture productivity and production success which relates to those people involve in farming as farmers. Recent insight reviled that farmers with quality of an entrepreneur will largely to succeed in agriculture based business. Hence, a lot of agriculture based business depends on agriculture entrepreneur in Malaysia. Thus, an assessment study was done for one of entrepreneurship programme held in Serdang and its relation to entrepreneurship development in Malaysia.
\end{abstract}

Methodology: The research design of this study employs qualitative research method. Data were gathered using social inquiry and in-depth interview techniques. It was used to develop a better understanding of the programme particularly in aspects of course content, their individual perception, and personal experience towards the programme. Sampling method was done via a purposive sampling. Five respondents were chosen and interviewed.

Findings and discussions: The interviews of respondents indicated most of farmers or agri-entrepreneur was male, ranging age from 20 to 50 years old and majority mean of agriculture field experience is three years. They became an entrepreneur by inner intuition, learn farming from their parents, and one of them had influenced by his surrounding environments. They were highly specialized in their field, business minded, and very committed to their business venture. All respondents know how to use the technological application of fertigation planting system in growing crops. Finding also shows early acceptance of mediated change to entrepreneurs whereby improving their knowledge, attitude and skill. Thus, entrepreneurship values showed in them are; 1) must have planning and aim, 2) past farming experience, 3) believed in their self, and 4) continue and eager to improve the farming business. This study shows one can succeed in doing business venture through the will power, able to control focus on aims and later will generate profit thereafter. As to succeed in life, they only have to continue pushing the limits and sustainability of their business.

Conclusions: The entire respondent shows improvement after the incubation programme and after finish the programme they become a successful entrepreneur where the evidence by their actions for at past, present experience, and in their future aims. This programme is a good programme meant to be as intermediary programme where improving the life of farmers and nurtured them becoming an experience agri-technology entrepreneur.

Keywords: extension education, entrepreneurship development, agriculture technology, technology usage

\section{Introduction}

Malaysia is generally driven by a service oriented industry whereby agriculture was placed at third ranks of government economic priority (Malaysian Statistics, 2010). Today, farmers are facing with an ever-expanding knowledge base of agriculture production and technological advancement. Thus, this develops serious arguments 
to strengthen farmers at the first place as well as develop extension educators towards developing human capital for the country. The entrepreneurship segment has led an important role in shaping our agriculture sector productivity, the GDP contribution, foreign exchange, and human capital development since 1957 Independence Day (MOA, 2010). Recent insight reviled that farmers with quality of an entrepreneur will largely to succeed in agriculture based business. The Productivity Report proves that to increase productivity, the actors who run the systems need to be empowered (MPC, 2013). As in the case of Malaysia, the entrepreneur programmme focuses on developing human capital for the agriculture industry. These types of programme always have an incubation period where growth progression of which people adopt technology through effective training and obtain agribusiness knowledge by using hands-on techniques. However, this study attempts to assess the programme in context of extension programme towards participation, reaction of farmers, and the training effectiveness. Agriculture productivity can be increased through an adoption of technology, good agriculture practices, and the farmers' internal strength. Thus, an assessment study was done for one of entrepreneurship programme held in Serdang and its relation to entrepreneurship development in Malaysia.

\subsection{Problem Statement}

In agriculture industry, a lot of agriculture based business depends on agriculture entrepreneur in Malaysia. Thus, the extension education is very important to stir the direction of agriculture development. There is a great concern for increasing agriculture production to meet the country's supply and demand. Rahim Md. Sail (2008) agreed that the level of technology adoption among farmers is still low especially on modern agriculture practices and it was the main factor contributes to low production of food crops. It is believed that the reduction in the yield gap can be accomplished by uptake of high yielding crop, usage of improved crop planting techniques and farm management. Thus, the key essence for agriculture success is to develop the human capital by focusing on the training programme. Only through an effective training would help the farmers excel and upgrade their skills to become an entrepreneur.

\subsection{Background of the Study}

Agriculture Youth Entrepreneur Incubation Programmme (AYEIP) is a programme aim to provide training and practices intended for youth that interested in agriculture field. This programme was established following the government policies to improve agriculture delivery service system controlled by Department of Agriculture (DOA) and funded under the Nine Malaysian Plan (Government of Malaysia, 2006). The programme outlines provide agriculture coaching and offer a 'hands-on' experience on farming knowledge. The AYEIP programme were located in DOA with two centers in Serdang and later has expanded in Kuala Lipis, Pahang; Titi Gantong, Perak and Center for Training Development and Extension in Besut, Terengganu. The programme target group range from age 18 to 35 years old or an agriculture institute graduates, university graduates, among youth, any general Malaysian citizen, and police retiree or pension army personnel (special requirements needed). The participants have to attend programme in full time basis and must finish eight months incubation at DOA. The entrepreneur who passed stringent training, possessed qualities and the incubation programme will be granted with a space for starting agribusiness at Permanent Food Production Park (PFPP) facility. The programme at PFPP is part of government strategic policy to develop a permanent zone for food productions in a large scale, commercial with high agri-technology practices, to cope with the demand on farm goods and health consciousness of the growing population. The project in Serdang holds a total acreage of 53.5 hectares with only 3.5 hectares is utilized by sharing land between 10 individual agriculture entrepreneurs.

\subsection{Research Objectives}

The primary objective of this study is to determine the achievement of extension programme by assessing farmer's accomplishment on entrepreneurship development and the usage of technology in their farm at PFPP, Serdang. The specific objectives are as follows:

1) To find out participation reasons among farmers in the programme;

2) To determine characteristics of entrepreneurship inside respondents;

3) To determine entrepreneurship programme strategies and training methods.

\section{Literature Review}

Most prominent, a young entrepreneur usually non-adequate in experience will seek for advisors or training experts that could give them guidance on technical knowledge about farming practices as to manage their business. In perspective of agriculture sustainability, the industry can only sustain production by ensuring the farmers are replenish, retrain, fully equipped them with new modern agricultural technologies and extension organization supports by providing trainings to them. 


\subsection{Difference of Extension Education, Services and Programmes}

Extension education in general is defined as a field of study dealing with informal education directed at the improvement of welfare of rural people. It also describes as a process of dissemination of useful information from research institution to the rural clientele through an extension delivery system for improving economic well-being of target group. According to Boone (1990), extension is human processes where technical information are fused together with one to another, integrated and planned to facilitate rural people achieve their full potentials. Further describe by Jon Chang Hong (1994) said that extension education largely emphasized on human as interface in technology transfer and they adopt new ideas. In reality of an extension system, it is the role of any entrepreneurship institution to facilitate the trainees by giving extension services. The entrepreneurship institution acts as a network bridge between scientists, the extension personnel and farmers or the clientele, where they meet together, changing information about new techniques to the farmers, exchange thoughts on modern farming, and sharing their problem to the scientists (Jitendra, 2007). However, the all of these activities is considered in planning of an extension programme with the purpose of helping entrepreneur to succeed in the programme.

\subsection{Difference of Extension Specialist, Extensionist and Extension Worker}

These three terms usually describe as important pertaining subject that have distinctive difference between one and another. First, the extension specialist's role is at the top management of institution where policies being drafted through outlining the mission and vision in extension agencies, who usually an qualified academician with specialization in extension education, programme planning, coaching, training of extension personnel, developing new extension methods, and other inter-related extension disciplines. Second, agriculture officer in government extension agencies is known as extensionist or extension educator, who involved in planning, has subordinate staff or extension workers, run implementation of extension programmes, acts as middleman where information were gathered, and distribute it to entrepreneur in training and assisted briefing session. As for the extension worker, they are the front runner level, meet face to face with farmers, and carry out all sorts of job pertaining to farmers satisfactory and their request.

\subsection{Agriculture Technology and Adoption through Technology Transfer Approach}

Technology is a study mechanical arts and applied sciences involving the development of technical knowledge. Technology is subjective and neutral. It should be perceived as medium for application of new improve method, additional ways of doing things (Jain \& Triandis, 1990) and expansion of new ideas that reliable to be use in any conditions (Ahmad, 2007). In addition, Hamilton and Singh (1992) defined technology transfer as the process of movement or transfer of information, technical know-how, and people among technical group functions. For some, technology basically referred to product offering by the technology producers (Khalil \& Berman, 1992). In agriculture perspective, farmers who wants to acquire agriculture technology needs to have values such as technology savvy and competent, easy technology acceptance, knowledgeable and ability to maintain the technology after acquiring it (Scott, 1992).

\subsection{Entrepreneurial Skills and Development}

According to McElwee and Robson (2005), suggested three types of skills that farmers should have in order to succeed in their business such as the entrepreneurial, managerial and technical efficacy of farming skills. Smilor (1997) and Kilby (1971) states that entrepreneurial skills develops from owner's activities, practical know-how for establishing and running a successful business; such as finance, accounting, marketing and production. There also some researchers describe them by values such as innovation, risk-taking, rational way of thinking, reasoning and opportunist (Timmons, 1999; Chen, 1998). However, the most important are the functional skills such as salesmanship and meta-task-level skill and most vital are recognizing hardship commitments that drive them towards success and sustainability of agribusiness (McElwee \& Bosworth, 2010).

\subsection{Conceptual Framework}

Leagans (1961)'s defined extension education as an applied science consisting of contents derived from researches, accumulated field experiences and relevant principles drawn from the behavioral sciences, and combine with useful technology. In this study, the conceptual framework shows hypothetical relationship among variables applied and determines the agri-entrepreneur reaction towards issues related to them, usage of technology in their farm, and effect of training programme to their way of working (Figure 1). Base on review of literature, we have identified some main variables for determine the objective addressed (Appendix B). The dependent variable is agri-entrepreneur or farmers, where peoples who make money by running and administrating agriculture businesses in cost conscious practice and financially risk takers. Meanwhile the 
independent variables are extension education absorption on knowledge, attitude, and skills, self-motivation, entrepreneurship values, barriers and challenges to participation, training programme (e.g. courses), technology application (e.g. GAP), personal control, and self-efficacy. For this study, thematic assessments were made on participation, reactions and individual changes (Summers, 1977). However, farm business, the nature of agriculture entrepreneur role, and the foundation behind the role of entrepreneurial were determined by focusing on relevant dimensions that characterized ones as an agriculture entrepreneur.

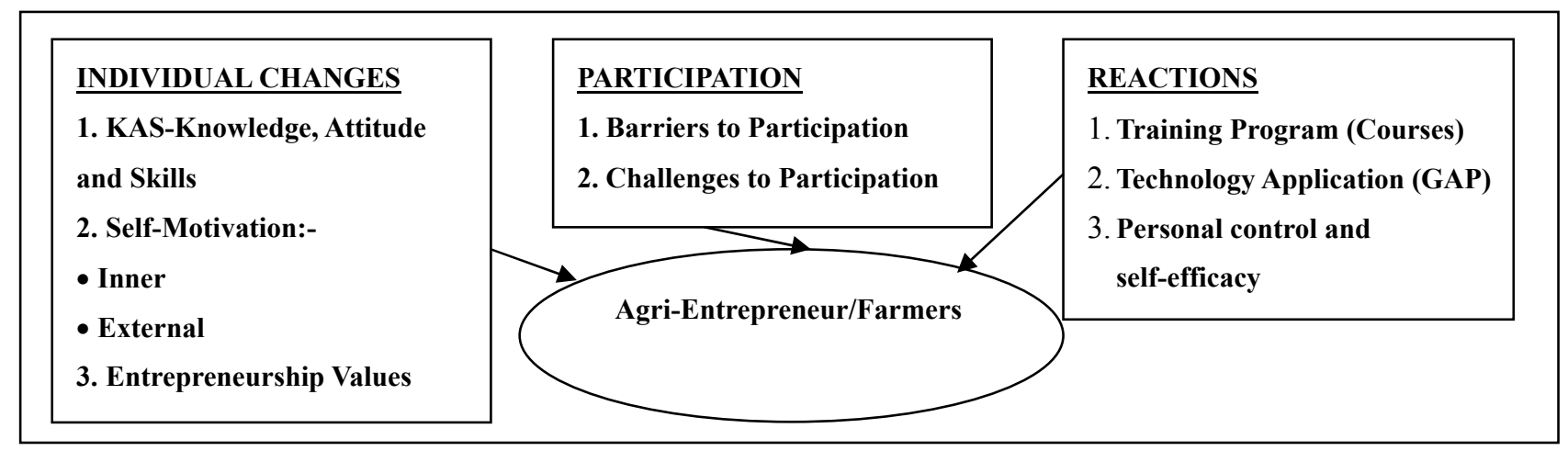

Figure 1. Conceptual framework

\section{Methodology}

For research purposes, this study is a qualitative research design. It was used to develop a better understanding of AYEIP programme in aspects of programme planning and its implementation from the personal experience of the instructor and the participants of the programme. Sampling was made using a purposive sampling (Patton, 2002). Data were gathered using social inquiry (Byron et al., 1975) and in-depth interview techniques. The reasons are to locate fruitful information in participant of the programme, their planning and learning experiences especially for better understanding of AYEIP programme in aspects of course content and perception of individuals towards the programme. All the potential respondent name and contact number were taken for arranging interview session based on their best suitable time. Sometime, one of them likes to be interviewed in leisure time at a restaurant near the Serdang town area. The respondents were the extension personnel and also four participants. The interview session was held following the respondent time and place as he/she wishes in face-to-face session. The interview session were conducted in Bahasa Malaysia at approximately 30 to 40 minutes. Digital recordings were made and all of them agreed to be recorded. Researcher also has taken some notes during conversation and it was summarized after the interview session. The entire respondent was very helpful and they also give the researcher a tour visit to their farm. After the interview session ends, researcher thanks each of the respondents for participating in this case study. All respondents have given their consent for the use of their information and no real names in the finding were used as to preserve anonymity. The study also used techniques such as prolong engagement, peer debriefing and member connections for ensuring the credibility of the findings.

\section{Findings and Discussion}

This programme used andragogy approach that support Malcolm S. Knowles (1973) assumptions. AYEIP entrepreneurs are highly interested, have aims, greatly motivated and being carefully selected for the programme. In 2011, AYEIP programme were declined trend of success where only thirty percent still maintain running agribusiness at Serdang PFPP and others leave to run their own farm in their village. Some of non-successor leave the field and jump into job employment. In upcoming years, this programme will not continue to be fund by the government, but the DOA will invite more existing farmers back to their center in Serdang at PFPP. Recent news informed by Faisal, the government willing to continue this programme with renewed system and refreshed strategies to draw braver participant.

From the interview sessions, the informant was reporting about their life story and the researcher records all of the explanation and saying. Thus, the result were simplified and arranged in thematic summary for easy explanation which has been taken from the voice records. The findings from in-depth interviews from four agri-entrepreneur indicated that most of farmers aka agri-entrepreneur were male, ranging age from $20 \mathrm{~s}$ to $50 \mathrm{~s}$ years old and majority mean of experience is 3 years in the agriculture field (Appendix A). They became an 
entrepreneur by inner intuition and learning from their parents and one of them had influence by his surrounding environments. They were highly specialized in their field, and for some; they are very committed to their business venture. All of them used technological application that is the fertigation techniques in planting crops system.

On in-depth interview findings shows early acceptance of mediated change to entrepreneurs whereby improving knowledge, attitude and skill. Results also in-line with Levine (2005) theory of fundamental of success where they know about their role in the industry, they are cost conscious, keeps updated records, have business development plan, , know how to deliver results, have self-confidence, self-respect, know what they wants and have gained their very own perspective in style of doing agriculture business. However, they are quiet shy on communication with the outsider especially to people which have high educational background. These shows they might needed to further invest on prolonged relationships and network search ability. It is because customer will not come if the seller is not nicer and do not have the power of attraction.

\subsection{Reasons for Participating in the Programme}

Reasons for their involvement are diverse. According to Ali said that, "I interested in joining this programme because to improve myself and I have to support my parent due to our less income." Moreover for Bakar, he explained, "My parent does not have much income......we (parents) only do farming in our small land.....the income just enough to support our basic needs monthly...... so I did join this programme to make something new for myself...none of my sibling is farmer, all of them (sibling) work either with government and private company..... but for me the likes of being businessman, as well as supports the family and become independent in doing business venture with the help of government.... who want to miss that chances."

This proves that no force imposed to become agri-entrepreneur from joining the programme, following the philosophy of participation and self-help. Ali shows an evident of principles of interest and needs. He has personal control and aware of the challenges opposed to them which supports the theory of planned behavior by Icek Ajzen (2002) research that aligned with principle of participation. The outcome from reasons they gave showed by their determination to succeed in agribusiness and increased in income at PFPP, where Ali and Bakar was indeed at average RM10,000 in income per cycle of production and they even want more.

\subsubsection{Challenges and Barriers of Participation}

From the interview of respondent, Ali (not real name) explained, "Many....there are many of participant could not withstand the challenge..... a lot of activities were done in bright sunny day and all the time we do it by our own self...... in fertigation system ...all activities. Maybe for some.....this work is hard for them."

He further added that "Participants withdrawn from the programme.....due to reasons such as already have another job, want to do business in the village, health problem of old parents, space are limited at PFPP and only selected participant with good qualities...... so this is the challenge......maybe they want to see whether who have the ability or not."

Bakar added more explanation, "True, there are many reasons participant give.....I just want to quote.....there are cases here where success farmer that institute believe can ready to move on to real world but after being place to other location or move to do business outside this place.....they eventually not succeed....from their explanation, they said factors such as land, finance or fund, cost of inputs, high infrastructure price, and market price uncertainties of crop they planted.....that is the first basis for establishing agriculture business."

The finding shows that the agriculture business is a high risk venture especially when they used the fertigation technology in farming crops. In Ali and Bakar, they somehow able to manage their idealistic needs, local responsibility and characters with their business culture. The challenges and barriers showed in them are their age, health conditions, body strength, land, finance or fund, cost of inputs, high infrastructure price, and uncertainties of crop prices.

\subsubsection{Farmers Motivation}

The majority of entrepreneur can be categorized in activity-oriented learners which explain by their action more towards farming activities rather than exploring to other aspects. Similar concept by Raymond (1999), the findings shows they actually learn through motivation that comes from inner intuition.

According to Latif, "I was a troublesome during my younger age..... and I manage to be the best of what I can do right now... I know from my friend about this programme...... I gain interest in this programme....long before them (Ali and Bakar) were in the programme.... but at that time I was still working with one of public cooperative company and I as the chief operation officer there. Later, after I have paid all my debts at the banks.......I said to 
myself that I should give others chances for my position and later I quit my job even thou I have high salary at the time.......... but I joint this because I changed and I like to do farming."

Latif favor condition where were met and the motivation increases. His conditions are such as environment, incentives motivate learning, internal motivation that more self-directive, learning is most effective when they really want it, and enhanced motivation through instructional materials. He has high spirit and it is believed that the remaining of farmers here in PFPP was the progressive farmers. From all the reasons explained above, the respondents seem to have their own reasons for joining the programme following their individual interest and needs. Moreover, their testament showed by their actions caring during farm tour visit after interview session ends.

\subsection{Characteristics of Entrepreneurship inside Respondent}

Finding suggested that there are some characteristics values of entrepreneurism inside respondent which could be categorized as; 1) they have planning and aim whether for their current business as usual or for future progress, 2) they have past farming experience where family traits, efficient farming values, and practices are being adopted, 3) believed in their self whether from inner, outer and trained by extension educator, and 4) continue and eager to improve the farming business as addressed in their aspiration towards sustainability of their farming business (Appendix A). This study shows one can succeed in doing business venture through the will power, able to control focus on aims and they will generate profit thereafter. Finding also identified numerous elements of entrepreneurship character among respondents such as goal oriented, and relevance in decision making, have gone through process of change and respected by other entrepreneurs. All these characteristics are the key ingredient for achieving goal in the entrepreneurship programme.

\subsection{Strategies and Training Method for Entrepreneurial Development in Serdang}

The AYEIP programme development concepts were jointly organized by Selangor State Government, Federal Government, and agriculture entrepreneurs. The State Government helps by giving authorization and gazetted the area as PFPP. The federal government on the other hand helps by sponsoring the development cost on basic infrastructure of PFPP. In contrast, trained agriculture entrepreneur runs their food crops production in the gazette land. Moreover, the programme also addressed several key aspects on Good Agricultural Practices application upon using fertigation technology systems. The main criterions of the agriculture entrepreneur success are they have to equip themselves with priority knowledge and skills.

According to the respondents, they said that the extension personnel always teaching them whenever they do farm visit, sometimes they give facilitation while on the farm. Topics that extension personnel emphasis are on the product early detection or farm traceability systems, record-keeping and internal audit, the planting materials, historical records and site management, substrate and land management, fertilizer solution management, irrigation and fertigation systems, crop protection and integrated pest management application, time schedule and harvesting, post-harvest treatment and handling, analysis of the crop pesticide residual, farm organic waste management, occupational safety and health of workers, environmental issues and laws, record complaints of farm products, and fulfilled legal requirements on standard farming activities (Appendix C).

From the programme perspective, the knowledge-flow is from research findings to extension personnel or mediator as to tackle farmer's problem while doing their farm activities. These could be summarized as in Figure 2. According to respondent interviewed, there were various ways of facilitation and training methods which have been designed to help the agriculture entrepreneur to change. However, they are free to choose whether willing to learn or they simply may not. This study shows the training center use six strategies to persuade, engage and empower them. The six strategies are very much related to learning approach of an individual and self-development within themselves (Figure 3). The extension educator also used reverse psychological practice as well as integrates motivation with religious aphorism which works as motivational control factor for triggering their self-courage. The entrepreneur showed element of fill needed and attached to the place. They often make frequent discussions with the extension educators and from this activity would help them to ease their burden, by social and mental support.

According to Farah, "I learn a lot from this place, the center (DOA) have bring me from nothing to having all of this advanced technology from Holland.... they believes in me thus giving me the opportunity to do it as my business venture..... without the government intervention in this programme..... all of this may not materialized." Further she added "I gain a new experience for many of them (extension educator), mentoring, supervising and they give me experience for succeed in life. I only have talent, idea and they respect me and provide me with infrastructure." 
Farah can be classed into philosophy of social progress where she more prone to spending their time and money at this center (PFPP) because she wants to learn and wanted a better life for herself. She shows character values such as self-realization, self-respect, self-motivated person, and self-determination. Although the respondent often do not know how to acquire what they want or how to make themselves but they have some fortitude to learn what is presented to them (Appendix A). The respondents tend to like the place (PFPP), the programme and willing to attach even after ending the eight months incubation.

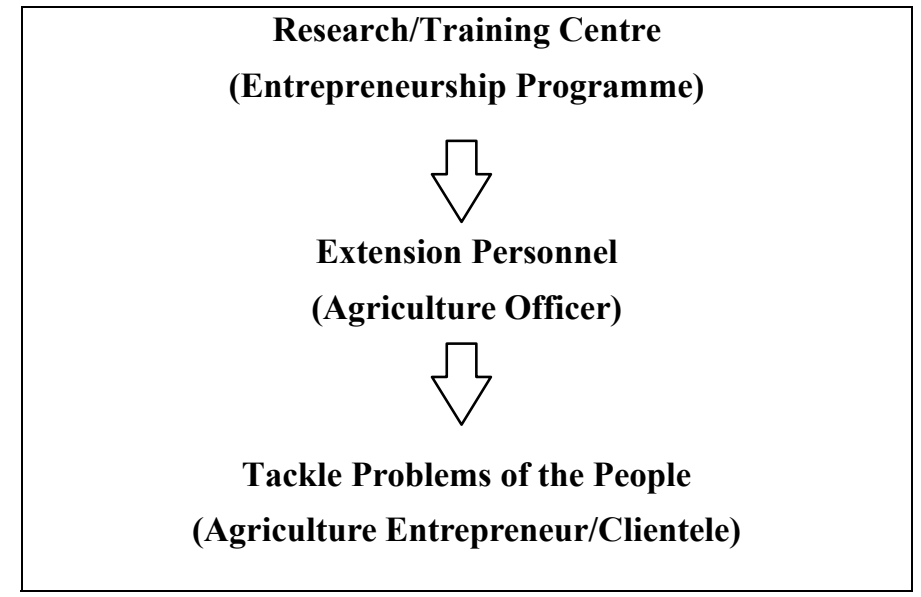

Figure 2. The programme knowledge-flow mechanism

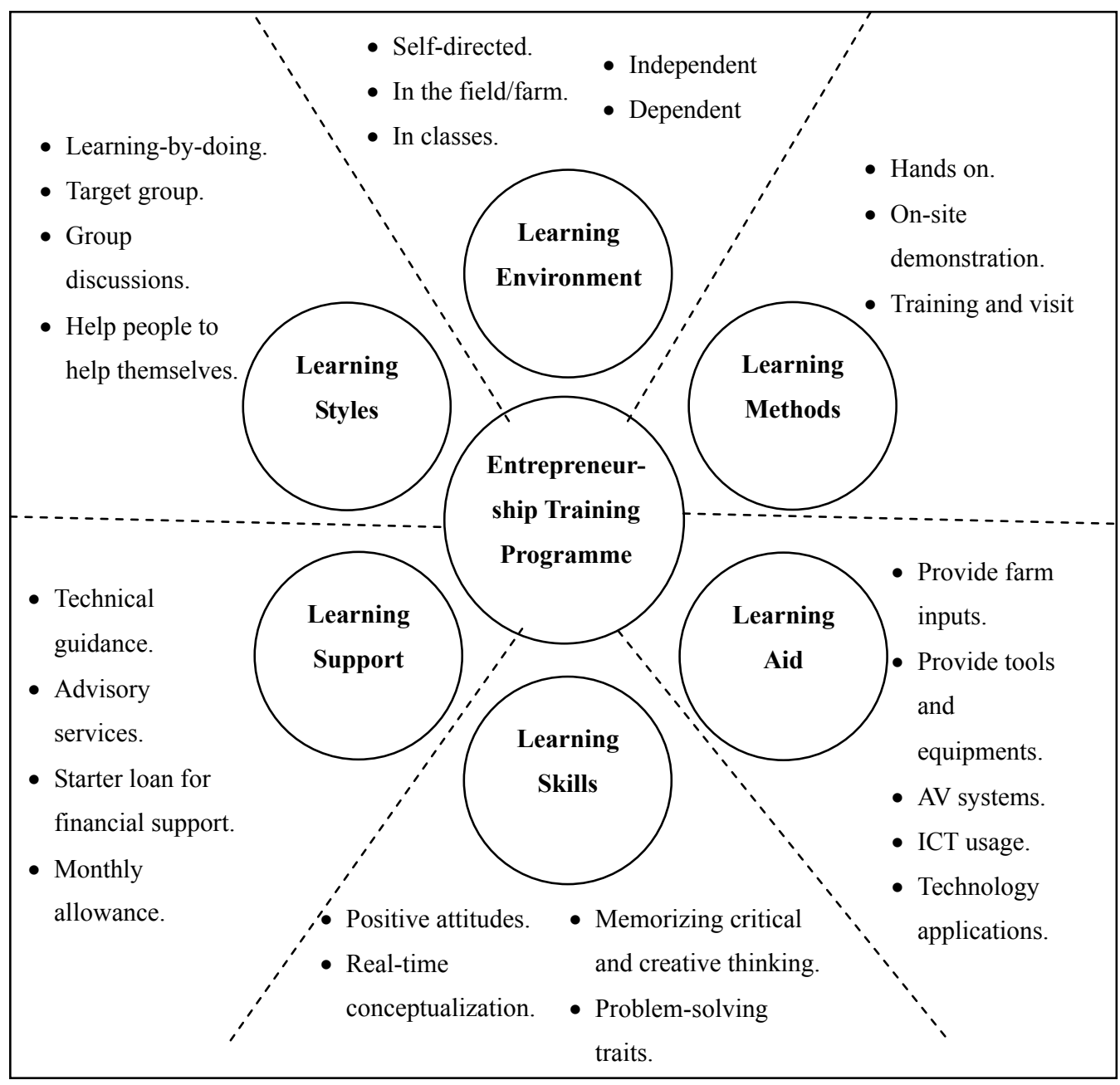

Figure 3. Strategies used in AYEIP programme 


\subsubsection{Extension Educator Role}

Findings were found that entrepreneur obey leaders that teach them. According to Bakar, "I had experience with the superior (Agriculture Officer)....there is a visit by the management from the Ministry...... officer urges us to keep up tidy the farm .......and I give my help to them without question ask ....I do as accordingly."

Furthermore, the most important is the role of extension educator in the institution that in line with philosophy of leadership and local responsibility (Azizan et al., 2011). From interview of extension educator, he perceived his role as personal satisfaction and to fulfill his generous aim to help agri-entrepreneur achieve their goal that bigger than the extension educator personal concern.

The evident shown by Faizal saying, "We as an catalyst to expand farmers potential to maximum.......selected agri-entrepreneur to explore their limit.... as we giving our full support and training on what they want to learn and upon asked by the entrepreneur." This explanation showed the extension educator already know their role on what to do and what need to be done which in line with organization goals (Appendix C).

\section{Recommendations}

Based on the findings, there are some recommendation list out for improvement and action by the people involved in this study. The recommendations are such as follows:

a. The government should emphasize on sustainability of the programme and stressed more on acceptance of new commercialized technology method rather than traditional method.

b. The extension educator should be empowered with skills on how to influencing people, negotiation skills and also technical knowledge on how to empower the entrepreneurs in amicable environment.

c. The training activities based on what they wanted to learn is not valid anymore. The extension personnel must add training of the future in term of what will be, what if, and what ought to be.

d. The programme content has to be a designed activity with achievable goals. Areas to strengthen are technical skill in farming business, entrepreneurial skills and farm managerial skills. This would help them to survive in competitive agribusiness environment.

e. Provider of the programme should search new strategies as to draw more new comers. The programme should be open as second-chance educations to person who really interested to be an entrepreneur.

\section{Conclusion}

In conclusion, the first objective was farmers' reasons for participating the programme shows agri-entrepreneur is aware of their role in the nation development and agriculture industry which can be seen by their live experience and agribusiness development progress. For the second objectives was determine the characteristics of entrepreneurship inside respondent were based on interest and needs. The entire respondent shows improvement after the incubation programme. Moreover they become a successful entrepreneur which evidence by their actions for at past, present and future aim. The entrepreneur characteristics assessment must be considered before selecting the best practitioner of modern agriculture entrepreneur. In addition, the last objective was determined about programme strategies and training methods that relate to their knowledge, attitude, skills, and aspirations have successfully addressed. This shows that the programme should be prolonged and funded back by the government. Finally, this programme was a good programme meant to be as intermediary programme where improving the life of farmers and nurtured them becoming an experience agri-technology entrepreneur.

\section{Acknowledgements}

I would like to thank the team for assistance in collecting the required information and making positive comments to improve the paper is gratefully acknowledged comments are acknowledged. This research is funded by the UPM Long Run Research Grant Scheme (LRGS) P6.1 (5525018) under the Ministry of Science, Technology and Innovation (MOSTI), Malaysia. The views and mistakes expressed are my own.

\section{References}

Ahmad, F. M. S. (2007). Agriculture Extension and Its Roles in Ensuring Food Safety, Quality and Productivity in Malaysia. Proceeding of 9th International Students Summit on Food, Agriculture and Environment in the New Century. Tokyo University of Agriculture, Japan. Retrieved December 12, 2013, from http://www.nodai.ac.jp/cip/iss/english/9th_iss/fullpaper/1-2-1upm-Fikri.pdf

Azizan, A., Azahari, I., Jasmin, A. S., \& Hayrol, A. M. S. (2011). Competency of Agriculture Extension Officers: The case of paddy development area in Selangor, Malaysia (pp. 42-56). Paper presented at the Seminar 
Hasil Penyelidikan IPSAS, Universiti Putra Malaysia.

Bandura, A. (1986). Social foundation of thought and action: A social cognitive theory. Englewood Cliffs, NJ: Prentice Hall.

Boone, E. J. (1990). Crossing Lines. Journal of Extension, 28(3). Retrieved October 25, 2007, from http://www.joe.org

Brockett, R. G., \& Hiemstra, R. (1991). Self-direction in adult learning: Perspectives on theory research and practice. New York: Routledge.

Cross, K. P. (1981). Adults as learners. San Francisco: Jossey-Bass.

Government of Malaysia. (2006). Ninth Malaysian Plan. The Prime Minister's Department. Putrajaya: Government Printer.

Government of Malaysia. (2010). Tenth Malaysian Plan. The Economic Planning Unit Prime Minister's Department, Putrajaya: Government Printer.

Hamilton, W., \& Singh, H. (1992). The evolution of corporate capabilities in emerging technologies. Interfaces, 22(4), 13-23. http://dx.doi.org/10.1287/inte.22.4.13

Hong, J. C. (1994). Technology Transfer and Human Resource Development. Emerald Full text, 26(11), 17-21.

Houle, C. O. (1961). In B. J. Keintz (Ed.), The inquiring mind. Madison: University of Wisconsin Press. Retrieved form http://www.scribd.com/doc/24728065/A-Qualitative-Analysis-of-Adult-Learners

Icek, A. (2002). Perceived behavioral control, self-efficacy, locus of control, and the theory of planned behavior. Journal of Applied Social Psychology, 32(4), 665-683. http://dx.doi.org/10.1111/j.1559-1816.2002. tb00236.x

Jain, R. K., \& Triandis, H. C. (1990). Management of Research and Development Organizations: Managing the Unmanageable, John Wiley \& Sons, New York. In Management Control Systems For R\&D Activities In Government Sector: A Case Of Indonesia. International Review of Business Research Papers, 5(3), 26-33.

Jitendra, C. (2007). Introduction to Agricultural Extension Education (pp. 1-66). R. B. S. College, Bichpuri.

Johnstone, J. W. C., \& Rivera, R. J. (1965). Volunteers for learning: A study of the educational pursuits of adults. Hawthorne, NY: Aldine de Gruyter.

Khalil, T., \& Berman, E. M. (1992). Technological Competitiveness in the Global Economy: A Survey. International Journal of Technology Management, 7(445), 347-358.

Kilby, P. (1971). Enterpreneurship and economic development. The Free Press, New York.

Knowles, M. S. (1973). The adult learner: A neglected species. Houston: Gulf.

Knowles, M. S. (1980). The modern practice of adult education: From pedogody to andragody (2nd ed.). New York: Cambridge Books.

Leagans, J. P. (1961). Extension Education for Community Development. In M. G. Kamath (Ed.), Extension Education in Community Development (pp. 1-26). India. Glasgow Printing Co.

Levine, S. R. (2005). The six fundamentals of success: The rules for getting it right for yourself and your organization. Singapore: Marshall Cavendish Business.

Malaysian Statistics. (2010). National Product and Expenditure Accounts Third Quarter 2011 (Updated: 18/11/2011). Retrieved January 5, 2012, from http://www.statistics.gov.my/portal/

Mazanah, M. (2001). Adult and Continuing Education in Malaysia. Serdang: Universiti Putra Malaysia Press.

Mazanah, M., \& Carter, G. L. (2002). Designing and Facilitating Adult Learning. Universiti Putra Malaysia Press.

McElwee, G., \& Bosworth, G. (2010). Exploring the strategic skills of farmers across a typology of farm diversification approaches. Journal of Farm Management, 13(12), 819-838.

McElwee, G., \& Robson, A. (2005). Diversifying the farm: Opportunities and barriers. Finnish Journal of Rural Research and Policy, 4, 84-96.

Merriam, S. B., \& Brockett, R. G. (1997). The profession and practice of adult education. San Francisco: Jossey-Bass.

Merriam, S. B., \& Cafferella, S. C. (2007). Learning in adulthood: A comprehensive guide (3rd ed.). John Wiley 
\& Sons. Inc.: Jossey-Bass Publishers, San Francisco, California.

MOA. (2010). Annual Report Year 2010. Ministry of Agriculture. Government printer.

MPC. (2012). Productivity Report 2011/2012. Malaysian Productivity Council. Government printer. Retrieved from http://bpap.mpc.gov.my/APR/APR2012.pdf

Onyebinama, U. A. U., \& Onyebinama, I. C. (2010). Extension Education and Entrepreneurship Development in Nigerian Agriculture. Agricultural Journal, 5(2), 63-69. http://dx.doi.org/10.3923/aj.2010.63.69

Patton, M. Q. (2002). Qualitative research and evaluation methods (3rd ed.). Thousand Oaks: Sage Publications.

Raymond, J. W. (1999). Enhancing adult motivation to learn: A comprehensive guide for teaching all adults. Jossey Bass Higher and Adult Education Series, John Wiley and Sons.

Rudmann, C. (2008). Entrepreneurial Skills and their Role in Enhancing the Relative Independence of Farmers: Results and Recommendations from the Research Project Developing Entrepreneurial Skills of Farmers (pp. 1-115). Research Institute of Organic Agriculture, Frick, Switzerland.

Scott, M. B. (1992). Behavioral Aspects of Technology Adoption. Journal of Extension, 30(2), 1-5. Retrieved from http://www.joe.org/joe/1992summer/a4.html

Smilor, R. W. (1997). Entrepreneurship reflections on a subversive activity. Journal of Business Venturing, 12, 341-346. http://dx.doi.org/10.1016/S0883-9026(97)00008-6

Summers, J. C. (1977). Dimensions of programme effectiveness and accountability. Morgantown: West Virginia University, Office of Research and Development.

Timmons, J. A. (1999). New Venture Creation: Entrepreneurship for the 21st Century (5th ed.). Irwin McGraw Hill.

Valentine, T. (1997). Adult learners: Who participates and why. In S. B. Merriam, \& S. C. Cafferella (Eds.), Learning in adulthood: A comprehensive guide (3rd ed.). John Wiley \& Sons. Inc.: Jossey-Bass.

\section{Appendix A}

Table A1. List of respondent's interview in categories

\begin{tabular}{|c|c|c|c|c|}
\hline Categories & $\begin{array}{l}\text { Respondent } 1 \\
\text { (Ali)* }\end{array}$ & $\begin{array}{l}\text { Respondent } 2 \\
\text { (Bakar)* }\end{array}$ & $\begin{array}{l}\text { Respondent } 3 \\
\text { (Farah)* }\end{array}$ & $\begin{array}{l}\text { Respondent } 4 \\
\text { (Latif)* }\end{array}$ \\
\hline $\begin{array}{l}\text { 1) Gender, Marital } \\
\text { Status, Age, and } \\
\text { Highest } \\
\text { Education? }\end{array}$ & $\begin{array}{l}\text { Married Men Age } \\
\text { 20s SPM }\end{array}$ & $\begin{array}{l}\text { Married Men, two } \\
\text { kids Age 30s SPM }\end{array}$ & $\begin{array}{l}\text { Married Woman } \\
\text { with kids Age 40s, } \\
\text { SPM }\end{array}$ & $\begin{array}{l}\text { Married Men, five } \\
\text { kids Age 50s } \\
\text { Advance Diploma }\end{array}$ \\
\hline $\begin{array}{l}\text { 2) When you } \\
\text { finish the } 8 \text { month } \\
\text { incubation course? } \\
\text { Years of } \\
\text { experience in } \\
\text { agribusiness? }\end{array}$ & $\begin{array}{l}8 \text { month incubation } \\
\text { ended on Oct } 2007 \text {, } \\
\text { now } 3 \text { years } \\
\text { agri-experience }\end{array}$ & $\begin{array}{l}8 \text { month incubation } \\
\text { ended on Oct } 2007 \text {, } \\
\text { now } 3 \text { years } \\
\text { agri-experience }\end{array}$ & $\begin{array}{l}8 \text { month incubation } \\
\text { ended on Oct } 2007 \text {, } \\
\text { now }>3 \text { years } \\
\text { agri-experience }\end{array}$ & $\begin{array}{l}\text { (instant/selected } 20 \\
\text { year entrepreneur) } 3 \\
\text { years agri-experience }\end{array}$ \\
\hline $\begin{array}{l}\text { 3) Do you own a } \\
\text { company? }\end{array}$ & Own company & $\begin{array}{l}\text { Own cor } \\
\text { supply i1 }\end{array}$ & pany with & $\begin{array}{l}\text { Own com } \\
\text { multiple b }\end{array}$ \\
\hline $\begin{array}{l}\text { 4) Interest and } \\
\text { support? }\end{array}$ & Love to do farming & $\begin{array}{l}\text { Interested } \& \text { family } \\
\text { very supportive }\end{array}$ & $\begin{array}{l}\text { No option \& full } \\
\text { strength at will }\end{array}$ & $\begin{array}{l}\text { No option \& full } \\
\text { strength at will }\end{array}$ \\
\hline $\begin{array}{l}\text { 5) Recent courses } \\
\text { taken? }\end{array}$ & $\begin{array}{l}\text { EM, Compost } \\
\text { Course, \& Bokashi }\end{array}$ & $\begin{array}{l}\text { EM, Compost } \\
\text { Course, \& Bokashi }\end{array}$ & $\begin{array}{l}\text { Intensive training } \\
\text { using Holland } \\
\text { technology system }\end{array}$ & $\begin{array}{l}\text { N/A-On farm work } \\
\text { experience }\end{array}$ \\
\hline $\begin{array}{l}\text { 6) Starting point } \\
\text { after incubation } \\
\text { and incentive } \\
\text { given? }\end{array}$ & $\begin{array}{l}6 \text { month } \\
\text { preparation }\end{array}$ & 6 month preparation & $\begin{array}{l}\text { Willing to get expert } \\
\text { help from Holland, } \\
\text { starts exactly after } \\
\text { incubation. }\end{array}$ & 6 month preparation \\
\hline $\begin{array}{l}\text { 7) Planting } \\
\text { preparation? }\end{array}$ & $\begin{array}{l}2 \text { unit x } 30 \text { x 90m } \\
(<3 \tan ) .\end{array}$ & $\begin{array}{l}2 \text { unit } \times 30 \times 90 \mathrm{~m} \\
(>3 \tan ) .\end{array}$ & $\begin{array}{l}4 \text { unit } \times 30 \times 90 m \\
(>7 \tan ) .\end{array}$ & $\begin{array}{l}2 \text { unit } \times 30 \times 90 \mathrm{ft} \\
(>3 \tan ) .\end{array}$ \\
\hline 8) Technological & Shelter \& Polybags & Shelter \& Auto pot & Shelter \& Holland & Shelter \& Polybags \\
\hline
\end{tabular}




\begin{tabular}{|c|c|c|c|c|}
\hline Categories & $\begin{array}{l}\text { Respondent } 1 \\
\text { (Ali)* }\end{array}$ & $\begin{array}{l}\text { Respondent } 2 \\
\text { (Bakar)* }\end{array}$ & $\begin{array}{l}\text { Respondent } 3 \\
\text { (Farah)* }\end{array}$ & $\begin{array}{l}\text { Respondent } 4 \\
\text { (Latif)* }\end{array}$ \\
\hline application in farm & $\begin{array}{l}\text { fertigation system, } \\
\text { GAP, \& IPM }\end{array}$ & $\begin{array}{l}\text { fertigation system, } \\
\text { GAP, \& IPM }\end{array}$ & $\begin{array}{l}\text { fertigation system \& } \\
\text { sensor tech, GAP, \& } \\
\text { IPM }\end{array}$ & $\begin{array}{l}\text { fertigation system, } \\
\text { GAP, \& IPM }\end{array}$ \\
\hline $\begin{array}{l}\text { 9) Farming } \\
\text { background and } \\
\text { family history? }\end{array}$ & $\begin{array}{l}\text { Parent farmer, Help } \\
\text { in palm oil farm, } \\
\text { banana, \& paddy }\end{array}$ & $\begin{array}{l}\text { Parent farmers, } \\
\text { Manage family's } \\
\text { palm oil farm \& } \\
\text { planted lemon grass }\end{array}$ & $\begin{array}{l}\text { Parent farmer, help } \\
\text { in family small } \\
\text { agribusiness }\end{array}$ & $\begin{array}{l}\text { Live in village, } \\
\text { businessman \& } \\
\text { previously has lots of } \\
\text { business failure }\end{array}$ \\
\hline $\begin{array}{l}\text { 10) Values that } \\
\text { moves you } \\
\text { further? }\end{array}$ & $\begin{array}{l}\text { Agriculture is } \\
\text { ordinary, no } \\
\text { specialty, \& strive } \\
\text { to success }\end{array}$ & $\begin{array}{l}\text { Agriculture is full of } \\
\text { challenges from } \\
\text { social, physical \& } \\
\text { rolling capital. }\end{array}$ & $\begin{array}{l}\text { Must do good to } \\
\text { crop, discipline, } \\
\text { planned aim \& } \\
\text { challenge yourself. }\end{array}$ & $\begin{array}{l}\text { God given, strength } \\
\text { to move further, } \\
\text { politic \& already } \\
\text { secure market }\end{array}$ \\
\hline $\begin{array}{l}\text { 11) Current } \\
\text { farmer's income } \\
\text { per cycle? }\end{array}$ & $\begin{array}{l}\text { Avg RM10,000 } \\
\text { (Avg } 4 \text { cycle) }\end{array}$ & $\begin{array}{l}\text { M11,000 (Avg } 4 \\
\text { ycle) }\end{array}$ & $\begin{array}{l}>\text { RM } 30,000 \text { (Avg } 4 \\
\text { cycle) }\end{array}$ & $\begin{array}{l}\text { At par RM15,000 } \\
\text { (Avg } 4 \text { cycle) }\end{array}$ \\
\hline $\begin{array}{l}\text { 12) Farmer's } \\
\text { income aim? }\end{array}$ & $\begin{array}{l}\text { Aim income: } \\
\text { RM3,000/month }\end{array}$ & $\begin{array}{l}\text { Aim income: } \\
\text { RM3,000/month }\end{array}$ & $\begin{array}{l}\text { Aim income: } \\
\text { RM6,000/month }\end{array}$ & $\begin{array}{l}\text { Aim income: Add } \\
\text { RM3,000/month }\end{array}$ \\
\hline $\begin{array}{l}\text { 13) Farming } \\
\text { details and types } \\
\text { crop planted? }\end{array}$ & $\begin{array}{l}\text { Self-running, } \\
\text { planted tomato } \\
\text { cherry \& rock } \\
\text { melon etc. }\end{array}$ & $\begin{array}{l}\text { elf-running, } \\
\text { lanted cucumber, } \\
\text { mato \& rock } \\
\text { elon etc. }\end{array}$ & $\begin{array}{l}2 \text { worker, planted } \\
\text { tomato \& rock melon } \\
\text { etc. }\end{array}$ & $\begin{array}{l}\text { Able to employ } 3 \\
\text { worker, planted chilli } \\
\text { etc. }\end{array}$ \\
\hline $\begin{array}{l}\text { 14) What's your } \\
\text { future planning for } \\
\text { your farming } \\
\text { business? }\end{array}$ & $\begin{array}{l}\text { Future Aim: } \\
\text { Market, testing } \\
\text { GAP, \& cost } \\
\text { reduction }\end{array}$ & $\begin{array}{l}\text { Future Aim: } \\
\text { Modified planting } \\
\text { medium \& increase } \\
\text { function of } \\
\text { fertigation sys. }\end{array}$ & $\begin{array}{l}\text { Future Aim: Trial } \\
\text { using new tech \& } \\
\text { Sustainability \& } \\
\text { increase efficiency }\end{array}$ & $\begin{array}{l}\text { Future Aim: } \\
\text { Modified planting } \\
\text { medium, cheaper } \\
\text { source. }\end{array}$ \\
\hline $\begin{array}{l}\text { 15) Do you think } \\
\text { the programme is } \\
\text { effective? (Is the } \\
\text { programme } \\
\text { effective and } \\
\text { benefit you) }\end{array}$ & $\begin{array}{l}\text { Yes, the hands-on } \\
\text { and real life } \\
\text { experience. }\end{array}$ & $\begin{array}{l}\text { Yes, I learn to use } \\
\text { new farming } \\
\text { method and gain } \\
\text { better income. }\end{array}$ & $\begin{array}{l}\text { Able to open farm, } \\
\text { use the knowledge } \\
\text { learn in the } \\
\text { programme, and } \\
\text { generate more } \\
\text { income. }\end{array}$ & $\begin{array}{l}\text { Able to apply } \\
\text { fertigation } \\
\text { knowledge, \& able to } \\
\text { produce in small } \\
\text { space with higher } \\
\text { production. }\end{array}$ \\
\hline $\begin{array}{l}\text { 16) What do you } \\
\text { expect from the } \\
\text { programme }\end{array}$ & $\begin{array}{l}\text { To improve income } \\
\text { and help parents }\end{array}$ & $\begin{array}{l}\text { To upscale } \\
\text { livelihood and be a } \\
\text { successful } \\
\text { entrepreneur }\end{array}$ & $\begin{array}{l}\text { To generate better } \\
\text { income }\end{array}$ & $\begin{array}{l}\text { To use the } \\
\text { technology to } \\
\text { modernize farming } \\
\& \text { to succeed in } \\
\text { farming business }\end{array}$ \\
\hline
\end{tabular}

*All the names are pseudonym

\section{Appendix B}

Base on review of literature, we have identified some main of variables to determine the objective addressed such as below.

Table B1. The independent variables

\begin{tabular}{lll}
\hline No. & Independent Variables & Explanations \\
\hline 1 & $\begin{array}{l}\text { Extension } \\
\text { (KAS) }\end{array}$ & $\begin{array}{l}\text { Extension education is an education and it is bringing a desirable change in } \\
\text { behavior (knowledge, skills and attitudes) of rural people to improve their } \\
\text { social, economic and psychological status (Chauhan, 2007) }\end{array}$ \\
2 & $\begin{array}{l}\text { Entrepreneur-ship } \\
\text { Values }\end{array}$ & $\begin{array}{l}\text { Entrepreneurship values assessed are their ability to accomplish something } \\
\text { from an addressed theme includes planning and aim, farming experience, } \\
\text { self-actualization, and eagerness to improve the farming business } \\
\text { Success is the indicator for assessing people and in motivation aspect. The } \\
\text { phrases "success is more predictably motivating than is failure" was a key } \\
\text { aspect in entrepreneurial development which means that success is the } \\
\text { indicator for assessing people and in motivation aspect, the success is a dream } \\
\text { that can and must be achieved. }\end{array}$ \\
\hline
\end{tabular}




\begin{tabular}{lll}
\hline No. Independent Variables & Explanations \\
\hline 4 & $\begin{array}{l}\text { Technology } \\
\text { Application }\end{array}$ & $\begin{array}{l}\text { Technology is increasingly becoming a veritable instrument for transforming } \\
\text { agriculture (Khalil \& Berman, 1992). Therefore, transfer of technology is a } \\
\text { process essential for the wide application and utilization of technology by one } \\
\text { or more users. } \\
\text { Training helps to increase farmers technological, educational, and social } \\
\text { capabilities. }\end{array}$ \\
5 & Training Programmes \\
6 & $\begin{array}{l}\text { Personal Control and } \\
\text { Self-efficacy }\end{array}$ & $\begin{array}{l}\text { Self-efficacy is dealing largely with the ease or difficulty of performing a } \\
\text { behavior and personal control is the controllability of an individual to the } \\
\text { extent of which performance is up to the actor (Ajzen, 2002). } \\
\text { The side backs of individual motivation towards success which in contrast } \\
\text { Barriers/Challenges to } \\
\text { limits the peoples participation. It is where reasons confined with the } \\
\text { individual intention to join, affix, linkage, attach, and interconnected with the } \\
\text { programme. }\end{array}$ \\
\hline
\end{tabular}

\section{Appendix C}

Table C1. Extension educator interview summary

\begin{tabular}{|c|c|}
\hline Categories & Respondent 5-Extension Personnel (Faizal) ${ }^{*}$ The name is pseudonym. \\
\hline $\begin{array}{l}\text { 1) Gender, Marital } \\
\text { Status, Age, \& } \\
\text { Education Level? }\end{array}$ & Married Men, Age 30s, Diploma in Agriculture \\
\hline $\begin{array}{l}\text { 2) Why this } 8 \text { month } \\
\text { incubation course is } \\
\text { necessary? }\end{array}$ & $\begin{array}{l}\text { "It is crucial and critical period to test them whether they have the ability to move } \\
\text { further or withdrawn from the programme courses. We encourage them to this as } \\
\text { training ground and give hand-on experience on what input that they want to acquire } \\
\text { or learn." }\end{array}$ \\
\hline $\begin{array}{l}\text { 3) What did you see in } \\
\text { the farmers? Do they } \\
\text { have the quality to strive } \\
\text { \& success? }\end{array}$ & $\begin{array}{l}\text { "We would like to see the will power inside the entrepreneurs and possible spirit of } \\
\text { eagerness for pursuing achievement or successes. Some of them have and few others } \\
\text { tend to withdrawn from the programme because can't stand the pressure as } \\
\text { entrepreneurs." }\end{array}$ \\
\hline $\begin{array}{l}\text { 4) Explain about the } \\
\text { principles of the } \\
\text { programme? }\end{array}$ & $\begin{array}{l}\text { "The programme is a hands-on learning approach which related to hand skills. } \\
\text { Hence, it also related to cognitive domain where the behavior related to individual } \\
\text { ability to knowing and realtime experience practices about knowledge they learned. } \\
\text { It is to facilitate farmers (entrepreneur) and equip themselves with knowledge and } \\
\text { skills.... People who accepted as participants will be provided with incentives such as } \\
\text { monthly allowance, food allowance and dormitory accommodation. The programme } \\
\text { aimed, participant will have sounded agriculture technical skills, agri-entrepreneur } \\
\text { skills, develop networking and be able to carry out business contract among other } \\
\text { establish entrepreneurs and also shape them up with confidence trait, skillful and } \\
\text { competitive....... After completion, only selected participant that shows capabilities } \\
\text { to excel will be grant a land in Permanent Food Production Park Serdang and also } \\
\text { be given incentives on agriculture inputs and infrastructure with at par agriculture } \\
\text { technology in place or could open agribusiness at their own land." }\end{array}$ \\
\hline $\begin{array}{l}\text { 5) What type of } \\
\text { programme do you teach } \\
\text { or offered here? }\end{array}$ & $\begin{array}{l}\text { "There are a lot of courses that outlined the programme such as Introduction to } \\
\text { Incubator Programme, Business Planning, Project/Business Proposal Preparation, } \\
\text { Guidelines for Good Agriculture Practices, Integrated Pest Management, Agricultural } \\
\text { Tractors and Small Machine, Open Planting System Project, Fertigation Planting } \\
\text { System in Greenhouse Structure Project, Agriculture Project Planting Using Insect } \\
\text { Resistance Structure, Farm Record, Agribusiness Marketing, and Farm Visit." }\end{array}$ \\
\hline
\end{tabular}

\section{Copyrights}

Copyright for this article is retained by the author(s), with first publication rights granted to the journal.

This is an open-access article distributed under the terms and conditions of the Creative Commons Attribution license (http://creativecommons.org/licenses/by/3.0/). 